\title{
Experimental justification of application of colloidal solutions of nano-particles of metals AuNP, AgNP, FeNP and CuNP in biogeotechnology of manufacture of vaccines
}

H. Ryzhenko,

Candidate of Biological Sciences

O. Horbatiuk,

V. Andriyashchuk,

O. Zhovnir,

T. Ukhovska,

Candidates of veterinary science

S. Tiutiun

Institute of Veterinary Medicine of the National Academy of Agrarian Sciences of Ukraine

L. Reznichenko,

S. Dybkova,

T. Gruzina

Candidates of biological sciences

Institute of Biocolloidal Chemistry named after F. D. Ovcharenko of the National Academy of Sciences of Ukraine

The purpose. To determine perspectives and expediency of use of nano-particles of metals in biogeotechnology of manufacture of vaccines, to determine stimulating densities nano-particles of gold, silver, copper, and iron for vaccine strains of bacteria. Methods. Microscopic, bacteriological, biological, chemical, variation-statistical. Results. The expediency of application of colloidal solutions of nano-particles of metals (gold, silver, copper, and iron), synthesized by method of chemical condensation, as perspective for biogeotechnology of manufacture of vaccines is justified. Biosafety of the selected AuNP, AgNP, FeNP, and CuNP is confirmed by negative tests on cyto- and genotoxicity, and also mutagenicity. Their individual densities which make active metabolic processes in cells of vaccine strains of causal organisms and promote increase of volumes of bacterial mass at manufacture of vaccines are specified. Conclusions. It is expedient to use synthesized by method of chemical condensation colloidal solutions of AuNP, AgNP, FeNP, and CuNP in biogeotechnology of manufacture of vaccines as growth stimulants of cells of vaccine strains of microorganisms.

Key words: nano-particles of metals, biosafety, cytotoxicity, geno-toxicity, mutagenicity, H+-ATF activity, bacterial mass, vaccine.

Now an integral part of scientific and technical progress in the world is the determining role of nanomaterials, which are synthesized by various methods and used in nanomedicine, nanopharmacology, nanotoxicology and nanopharmaceutics[1, 2].

A qualitatively new level of counteraction to infectious disease can be achieved through use of newest nanobiotechnologies and nanomaterials. Stability of the properties of metal nanoparticles depends on the method of their production, which are conditionally divided into groups: chemical synthesis, mechanosynthesis and ablative nanotechnologies [3-6].

Determination of modulation peculiarities of metal nanoparticles in biochemical processes in biosystems of different levels of organization, including cells of pathogenic microorganisms, opens new prospects for their application in the biotechnology of manufacturing specific preventive means $[7,8]$.

Scientists obtained data indicating the possibility of controlling and regulating the intensity of physiological and biochemical reactions in bacterial cells [9]. 
It has been established that biogenic metal nanoparticles are cofactors of the vast majority of biochemical processes in living systems, therefore their stimulating activity is a consequence of a complex biophysical-biochemical effect [10,11].

New trends in scientific progress in the application of metal nanoparticles in medicine, including veterinary medicine, are relevant issues in the solution of human needs, but pose risks concerning safety for civil society. In the countries of the European Union, the use of existing and new nanopreparations is strictly regulated at the legislative level.

In Ukraine, currently there is no single standardized system of methods for determining safety of means developed using nanotechnology, however, in the field of veterinary medicine, a number of methodological recommendations aimed assessing the safety of nanoparticles of metals for veterinary purposes that are components of immunobiological preparations have already been approved and adopted for practice [12-15]

The aim of the work was determination of the potential metal nanoparticles, experimental confirmation of the advisability of their colloidal solutions application synthesized by the chemical condensation method in biotechnology for the vaccines production; study the nature of the influence of AuNP and AgNP on the value of $\mathrm{H}+$-ATPase activity of membrane fractions of vaccine strains cells of microorganisms, determination of optimal certain concentrations of AuNP, AgNP, CuNP, FeNP to stimulate metabolic processes in C. perfringens type A cells to increase bacterial mass in a short period of culturing.

Material and methods. The work was performed in V. Ryzhenko laboratory of anaerobic infections. Nanoparticles of metals were synthesized in F.D. Ovcharenko Institute of Biocolloidal Chemistry of the NAS of Ukraine as the colloidal solutions with initial concentrations of the metal: AuNP $-38.6 \mu \mathrm{g} / \mathrm{ml}$, dimension 30.0 $\mathrm{nm}$; AgNP - $80 \mu \mathrm{g} / \mathrm{ml}$, dimension $30.0 \mathrm{~nm}$; CuNP - $32.0 \mathrm{mg} / \mathrm{ml}$, dimension $20 \mathrm{~nm}$; FeNP $-5.0 \mathrm{mg} / \mathrm{ml}$, dimension $40.0 \mathrm{~nm}$.

Studies on assessment of the potential hazards of metal AuNP, AgNP, CuNP, FeNP nanoparticles have been carried out using systemic biomarkers of cytotoxicity, genotoxicity, mutagenicity.

The cytotoxicity of the studied nanopreparations was evaluated by the cell viability test using the neutral red and in the MTT tests; genotoxicity using the method of DNA comets under alkaline conditions; mutagenicity by an anaphase method of counting chromosome aberrations in cells of the apical onion meristem (Allium cepa) [12].

A study of the effect of different concentrations of AuNP and AgNP on the value of the H + -ATPase activity of membrane fractions of E. coli strain "Rassvet-165" (non-hemolytic), E. coli strain "Zaporozhskaya-12" (hemolytic), P. multocida strain "Polonsky", L. monocitogenes strain "Agrofort", S. choleraesuis strain "Zaporozhsky-32", C. perfringens strain type A "Zaporozhye 96/130", C. perfringens strain type B "Polonsky131", C. perfringens type C strain "Slavutsky 97/132"; C. perfringens type D strain "Khmelnitsky"; C. septicum strain "Cherkassky-97", C. oedematiens strain "Zaporozhye-96", F. necrophorum strain "Rassvet" was carried out according to the level of accumulated inorganic phosphorus in the incubation medium by the FiskeSubbarow method in conventional units [12].

The following procedure was used to establish the experiment: from AuNP, AgNP, CuNP, FeNP matrix colloidal solutions three working dilutions were prepared in bottles No. 1, No. 2, No. 3 with $40.0 \mathrm{~cm}^{3}$ of liver infusion broth (LIB) with the addition of $10.0 \%$ sterile glucose solution and $5.0 \%$ sterile serum of cattle blood ex tempore in aseptic conditions. In bottles No. $110.0 \mathrm{~cm}^{3}$ were added; in bottles № $25.0 \mathrm{~cm}^{3}$; in bottles No. 31.0 $\mathrm{cm}^{3}$ of each of the research solutions of metal nanoparticles with initial concentrations. The test type A $C$. perfringens strain was cultured in Kitt-Tarozzi medium for 24 hours. The bacterial cell suspension of the pathogen was taken to sterile bottles under aseptic conditions, thoroughly mixed, labeled and used for inoculation in bottles with various metal nanoparticles at their use rate. Each rate of the studied metal nanoparticles was bottled into 4 vials of $10.0 \mathrm{~cm}^{3}$ volume. As a control, $10.0 \mathrm{~cm}^{3}$ of LIB with glucose and serum without nanopreparations were added into bottles. In all the research and control bottles, suspension of $C$. perfringens type A daily culture was added, sterile vaseline oil was added on the surface of the inoculeted medium to provide cultivation conditions to anaerobic ones. After inactivation of the bacterial suspension, the quantitative content of bacterial cells in $1.0 \mathrm{~cm}^{3}$ was conducted according to the optical turbidity standard [16]. The following research methods have been used: microscopic, bacteriological, biological, chemical, variational and statistical. 
Results of the research. Since the effect of nanoscale metals on living organisms is understudied, this gives ground to assess potential risks to human health, animals and state of the environment. Scientists of the laboratory carried out experimental studies related to the selection of metal nanoparticles depending on the method of their production. Previously, the nano aqua-chelates of argentum, iron, copper, zinc were investigated obtained using erosional explosive technology (Fig. 1).

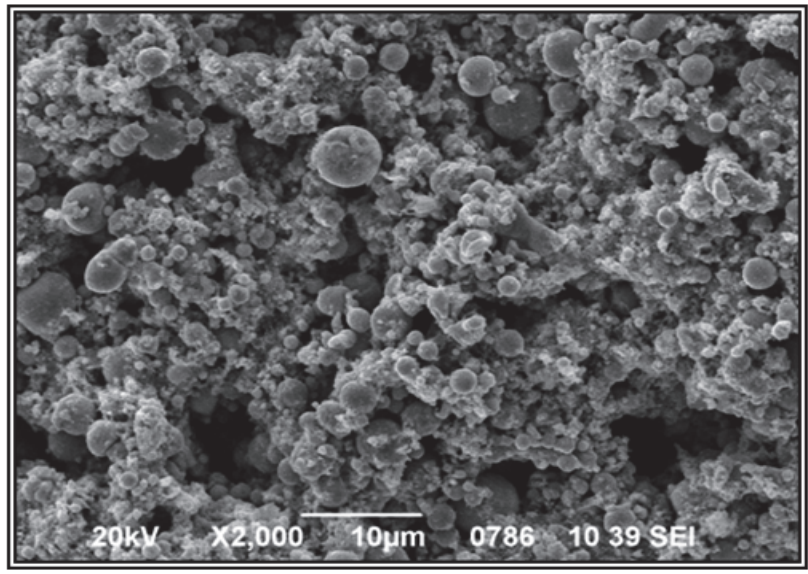

(A)

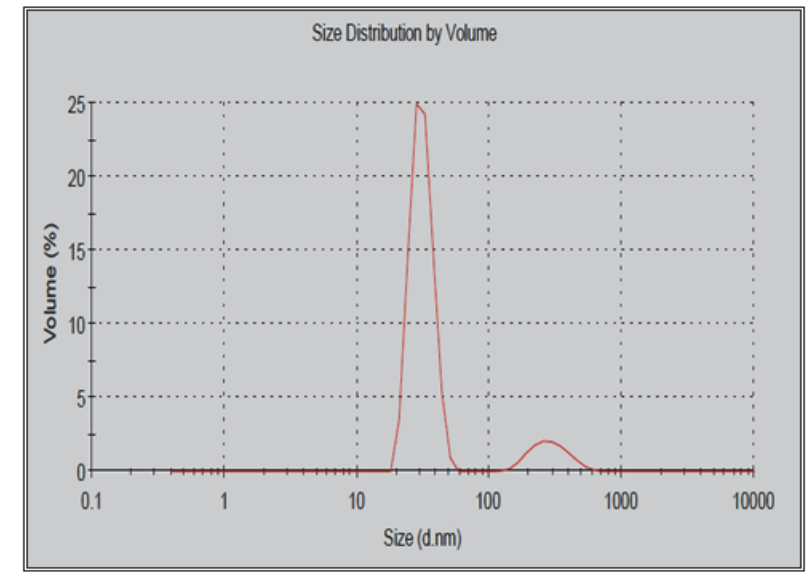

(Б)

Fig.1. The characteristics of silver nanoparticles by shape and size obtained by the erosional explosive method (A) and the parameters of laser correlation spectroscopy

After control checking the abovementioned nanopreparations with atomic absorption spectrophotometer, it was found that their concentration by metal content did not correspond to the concentrations declared by the manufacturer. In addition, according to the results of electron microscopy, these nanopreparations contained metals nanoparticles of various size: small, medium and large.

During the experimental studies, a certain concentration of the preparation by the metal was taken into account. The results of the studies revealed that all mentioned nanopreparations at certain concentrations had activated the growth of pathogenic microorganisms' strains at different time of their cultivation in a thermostat [17]. However, it was not possible to determine stable concentrations of nanopreparations that caused the most active culture growth, since after every culture inoculation in the presence of nanopreparations various indices of their effective concentration were obtained, which cause activation of metabolic processes in bacterial cells. Perhaps, these instable results related with a variety of initial concentrations of metal nanopreparations by metal after obtaining using erosional explosive method that each time lead to formation of different proportions of metal nanoparticles: small, medium and large.

The search for potential metal nanoparticles to use in biotechnology for the vaccines manufacturing was continued, and later scientists of the laboratory of the F.D. Ovcharenko Institute of Biocolloidal Chemistry experimentally substantiated the advisability of application of gold, silver, copper and iron metal nanoparticles colloidal solutions synthesized by chemical condensation in aqueous solution according to the developed original protocols. Chemical synthesis ensured the production of nanoparticles of the same size, concentration by metal, which was confirmed by the results of transmission electron microscopy and effected on the stability of the results (Fig. 2). Biorisk prevention remains a top priority concerning animal and human health as well as environmental safety for the producers of specific prevention means. 


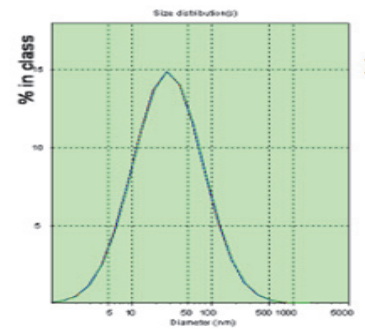

A

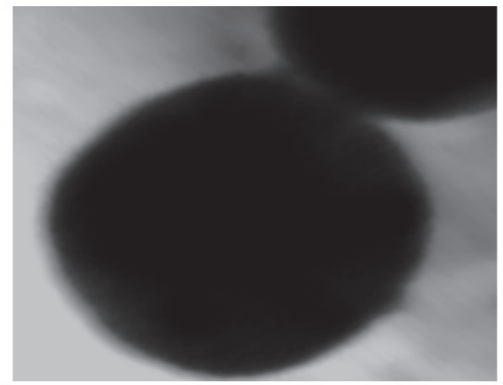

(II)

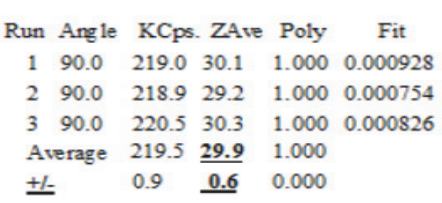

$\begin{array}{lllll}+1- & 0.9 & \underline{0.6} & 0.000\end{array}$

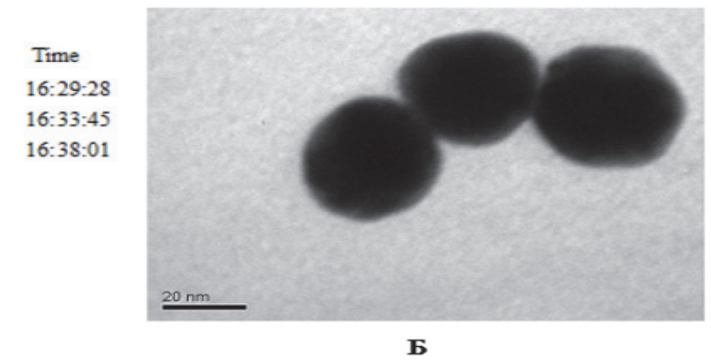

Б

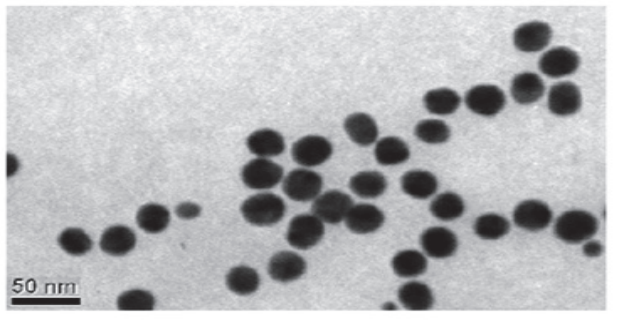

A

(III)

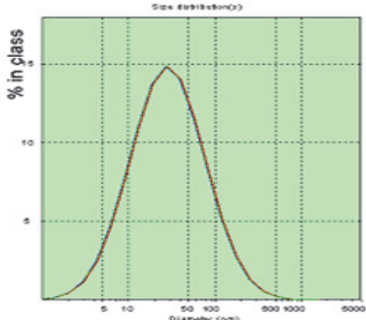

B

Fig. 2 Characteristics of metal nanoparticles by shape and size

Notes: I - (A) electron microscopic image of AuNP, (B) index of AuNP laser correlation spectroscopy; II - electron microscopic image of FeNP; III - (A) electron microscopic image of AgNP, (B) index of AgNP laser correlation spectroscopy.

Scientists of our laboratory together with the staff of the F.D. Ovcharenko Institute of Biocolloidal Chemistry carried out researches and biosafety of synthesized colloidal solutions (AuNP, AgNP, CuNP and FeNP) potential for biotechnology of vaccine production was confirmed by negative results concerning cytotoxicity, genotoxicity and mutagenicity (Table 1).

Table 1. Biosafety characteristics of silver and gold nanoparticles

\begin{tabular}{|l|l|l|l|}
\hline Criteria of safety & Safety Assessment Method & Nanoparticles AgNP & Nanoparticles AuNP \\
\hline \multirow{2}{*}{ Cytotoxicity } & crystal violet staining & Safe & Safe \\
\cline { 2 - 4 } & MTT- test & Safe & Safe \\
\hline Genotoxicity & Comet analysis & Safe & Safe \\
\hline Mutagenicity & Allium-test & Safe & Safe \\
\hline
\end{tabular}

Previous researches of the scientists of our laboratory on studying feasibilities of using synthesized colloidal solutions of gold, silver, copper and iron metal nanoparticles in biotechnology of veterinary immunobiological means production to activate growth processes of production strains of pathogens confirmed potential of their use.

In particular, according to the analysis of the results of studies on the character of the AuNP and AgNP effect in different concentrations on the $\mathrm{H}+$-ATPase activity of membrane fractions of aerobic and anaerobic bacteria of such pathogens as E. coli strain "Rassvet-165" (non-hemolytic), E. coli strain "Zaporozhskaya-12" (hemolytic), P. multocida strain "Polonsky", L. monocitogenes strain "Agrofort", S. choleraesuis strain "Zaporozhye-32", C. perfringens type A strain "Zaporozhye 96/130", C. perfringens Type B strain "Polonsky131", C. perfringens type C strain "Slavutsky 97/132", C. perfringens type D strain "Khmelnitsky", C. septicum strain "Cherkassky-97", C. oedematiens strain "Zaporozhye-96", F. necrophorum strain "Svitanok" it was found that for aerobic microorganisms better stimulating effect had gold nanoparticles, for anaerobic - silver ones. In addition, it was established that the response pattern of the specific $\mathrm{H}+$-ATPase activity of membrane fractions of aerobic and anaerobic pathogens had a distinct species and strain specificity, and therefore requires individual selection of the metal nanoparticles concentrations for each production strain of microorganisms used in biotechnology of vaccines production.

Considering the results of experiments on the effect of AuNP and AgNP in different concentrations on the membrane fractions' $\mathrm{H}+$-ATPase activity of microorganisms' vaccine strains, we conducted studies to 
determine the best individual stimulating concentrations of gold (AuNP), silver (AgNP), copper (CuNP), and iron (FeNP) nanoparticles, which activated metabolic processes in C. perfringens type A cells and contributed to the accumulation of the largest volumes of bacterial mass and established the optimal time for its cultivation.

According to the results of the studies on the AuNP effect on the metabolic processes of $\mathrm{Cl}$. Perfringens type A bacterial cells, it was found that microorganism culturing with nanopreparation in $0.965 \mu \mathrm{g} / \mathrm{ml}$ concentration for 36 hours provided a significant dynamic increase of bacterial mass in 2.06 times ( $p>0.01)$ by the growth factor compared to the initial data (Fig. 3).

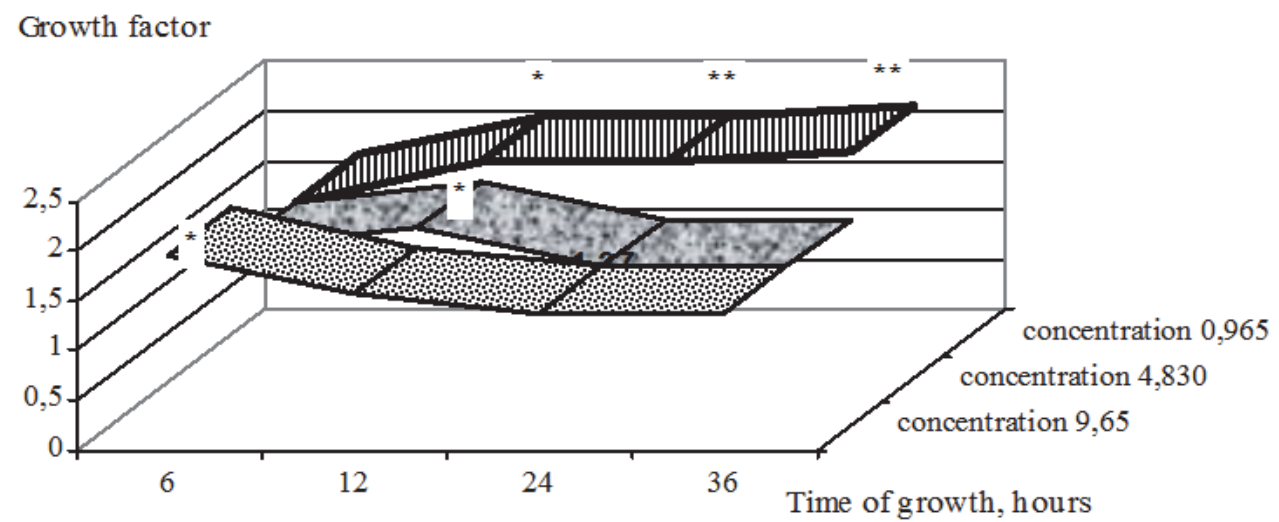

\section{Fig. 3. Dynamics of growth indices of C. perfringens type A bacterial cells by different terms of cultivation with various concentrations of AuNP Note: ${ }^{*}-\mathrm{p}>0.05 ; * *-\mathrm{p}>0.01 ; * * *-\mathrm{p}>0.001$, compared to the initial data}

Results of studies regarding the AgNP stimulation effect on the metabolic processes of $C$. perfringens type A showed that bacteria growth with $20.0 \mu \mathrm{g} / \mathrm{ml}$ of AgNP during 24 hours contributed to an increase in bacterial mass in 4.02 times by the growth factor ( $p>0.001$ ) compared to the initial data (Fig. 4).

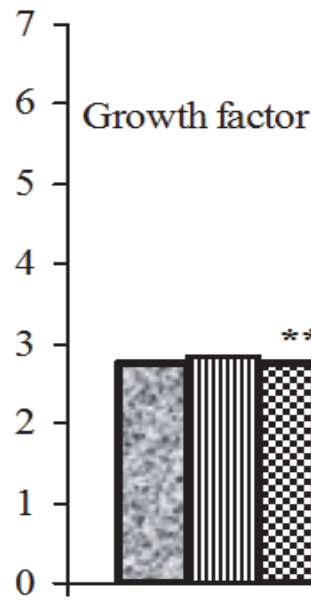

6

12

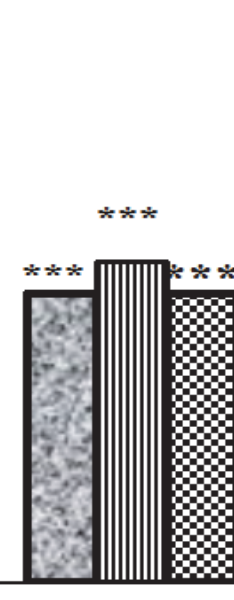

24
D concentation $20,0 \mu \mathrm{g} / \mathrm{ml}$ 血 concentration $10,0 \mu \mathrm{g} / \mathrm{ml}$ $\boldsymbol{B}$ concentration $2,0 \mu \mathrm{g} / \mathrm{ml}$

Fig. 4. The effect of various concentrations of AgNP on the growth of Cl. Perfringens type A bacterial mass.

Note: ${ }^{*}-\mathrm{p}>0.05 ; * *-\mathrm{p}>0.01 ; * * *-\mathrm{p}>0.001$, compared to the initial data

Studies of the CuNP stimulation effect on the metabolic processes of $C$. perfringens type A showed that bacteria growth with $0.040 \mu \mathrm{g} / \mathrm{ml}$ of nanoparticles of this metal during 24 hours caused increasing of bacterial mass in almost 4.0 times by the growth factor $(p>0.001)$ compared to the initial data (Fig. 5). 


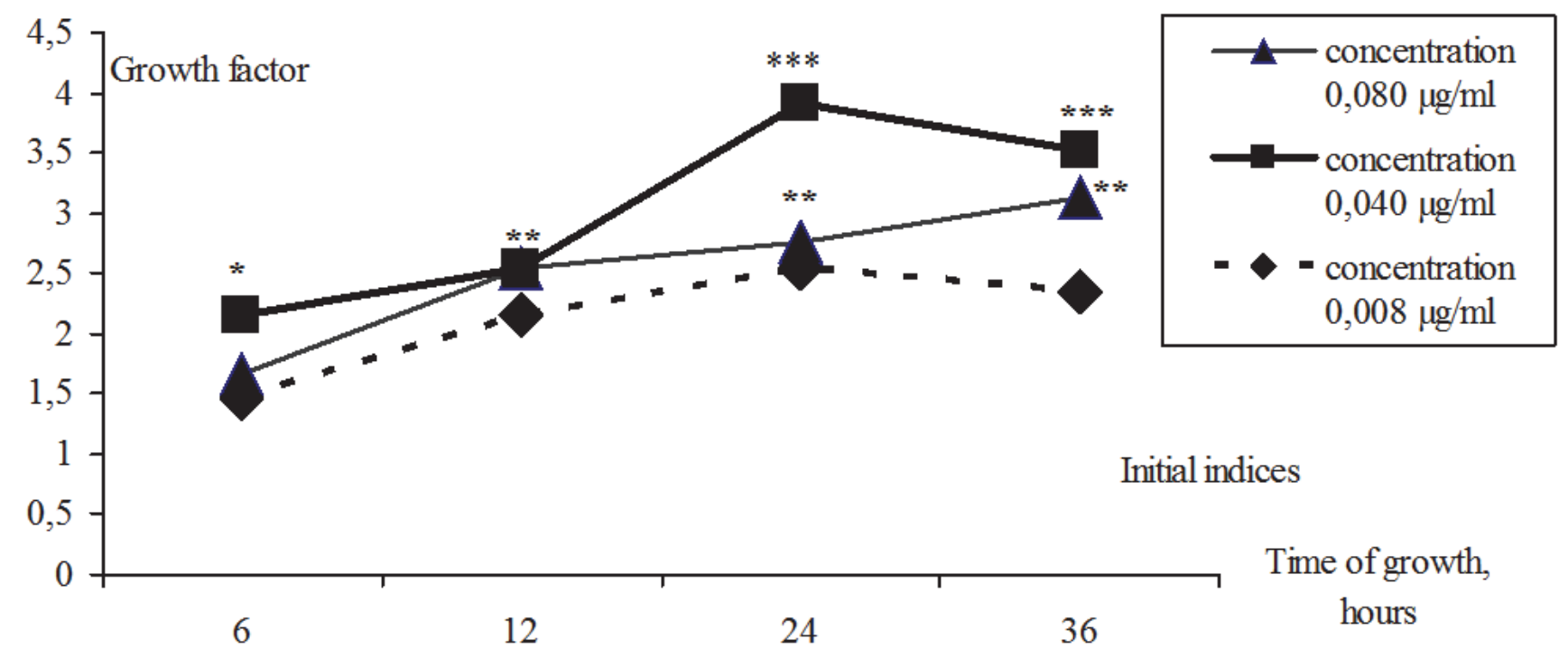

Fig. 5. Indices of $C$. perfringens type A growth factor at different terms of cultivation with $\mathrm{CuNP}$ of various concentrations.

Note: ${ }^{*}-\mathrm{p}>0.05 ; * *-\mathrm{p}>0.01 ; * * *-\mathrm{p}>0.001$, compared to the initial data

The optimal individual concentration of FeNP was $0.310 \mu \mathrm{g} / \mathrm{ml}$ as at this concentration bacterial mass of C. perfringens type A significantly increased in 23.5 times after culturing $(p>0.001)$ compared to the initial data (Fig. 6).

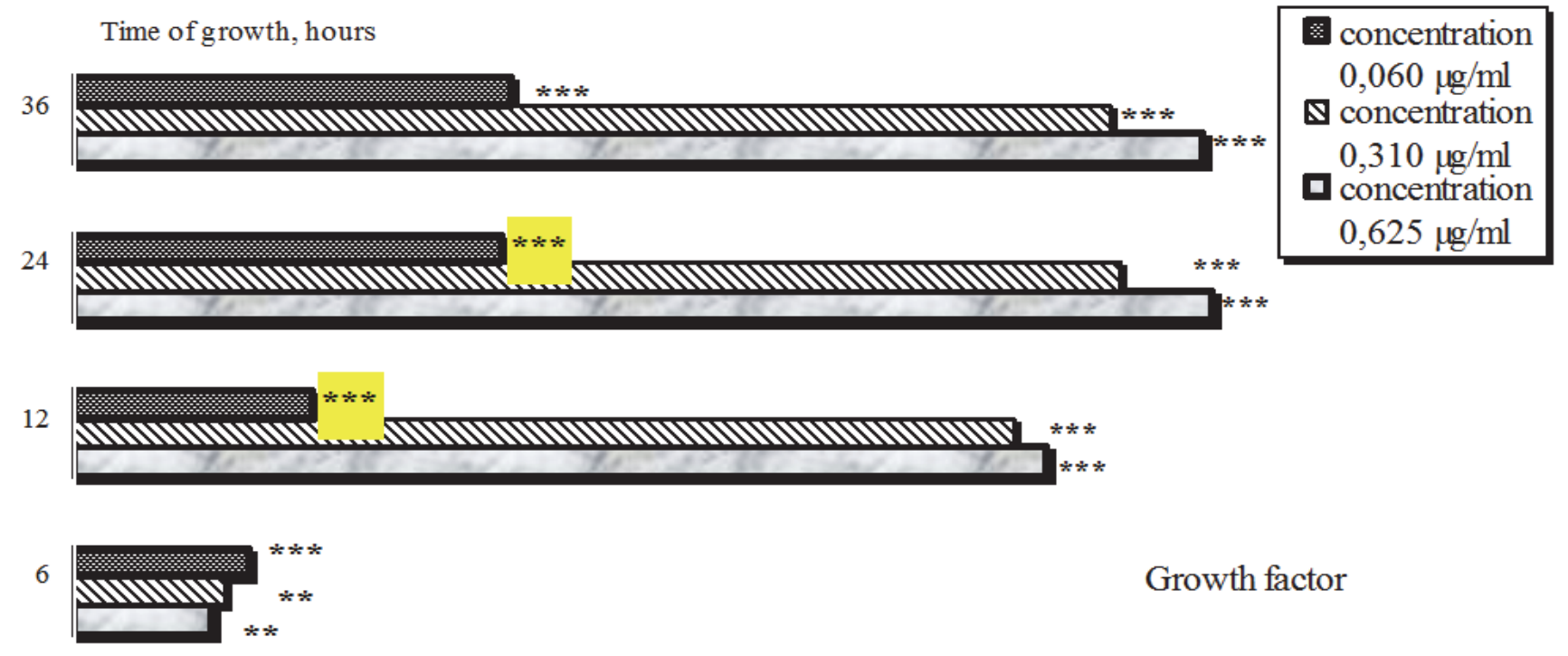

Fig. 6. The growth of the $C$. perfringens type A with different concentrations of FeNP and time of cultivation

Note: ${ }^{*}-\mathrm{p}>0.05 ; * *-\mathrm{p}>0.01 ; * * *-\mathrm{p}>0.001$, compared to the initial data

The obtained results of the research contribute to the improvement of technological processes in the biotechnology of vaccine production, and vaccines containing metal nanoparticles could probably effect positively on metabolic processes in animals organism, since they contain active biotic microelements: gold, silver, iron and copper nanoparticles. 


\section{Conclusions:}

1. It was experimentally substantiated feasibility of usage of silver, gold, copper and iron nanoparticles colloidal solutions synthesized by chemical condensation in an aqueous solution in the biotechnology of specific preventive means production. Their biosafety was confirmed by negative tests for cytotoxicity, genotoxicity and mutagenicity.

2. It was established that the response character of the specific $\mathrm{H}+-$-ATPase activity of aerobic and anaerobic pathogens membrane fractions had a distinct species and strain specificity and requires an individual selection of the metal nanoparticles concentrations for each production strain of microorganisms used in biotechnology for the vaccines production.

3. It was established that to stimulate metabolic processes of $C$. perfringens type $A$ and obtain significant volumes of bacterial mass in a short period of cultivation, the optimal individual concentrations of nanopreparations should be: AuNP - $0.965 \mu \mathrm{g} / \mathrm{ml}$; AgNP - $10.0 \mu \mathrm{g} / \mathrm{ml}$, CuNP $-0.040 \mu \mathrm{g} / \mathrm{ml}$, and FeNP -0.625 $\mu \mathrm{g} / \mathrm{ml}$.

Prospects for further research concerning study of the features of penetration, accumulation in the parenchymal organs of animals and elimination period of metal nanoparticles are very important issues for nanotechnology application.

\section{Bibliography}

1. Sahoo, S.K., Parveen S., \&Panda J.J. (2007). The present and future of nanotechnology in human health care. Nanomedicine, 3, 20-31.

2. Chen, Po. C., Mwakwari, S. C., \& Oyelere, A. C. (2008). Gold nanoparticles: from nanomedicine to nanosensing. Nanotechnology, Science and Application, 1, 45-66.

3. Aaron, J., E., de la Rosa, Travis, K.et al. (2008). Polarizition microscopy with stellated gold nanoparticles for robust, in-situ monitoring of biomolecules. Optic Express, Vol. 16, 3, 2153-2167.

4. Kaplunenko V.G., Kosinov N.V., \& Poljakov D.V. (2007). Poluchenie novyh biogennyh i biocidnyh nanomaterialov s pomoshh'ju jerozionno-vzryvnogo dispergirovanija metallov [Production of new biogenic and biocidal nanomaterials by erosional explosive dispersion of metals]. Proceedings from The Nanotechnologies and nanomaterials for biology and medicine: Nauchno-prakticheskih konferencij s mezhdunarodnym uchastiem (11-12 oktiabria 2007 goda) - Scientific and practical conferences with international participation. (pp. 134137). Novosibirsk SibUPKju [in Russian].

5. Kosinov, M. V., \& Kaplunenko, V. G. Sposib otrymannja koloi'dnyh metalevyh nanochastynok «Erozijnovybuhova nanotehnologija otrymannja koloi'dnyh metalevyh nanochastynok» [Method of obtaining of colloidal metal nanoparticles "Erosional explosive nanotechnology of colloidal metal nanoparticles obtaining"]. Patent UA on useful model (2008.01) № 29450./ MPK (2006) V01 J13/00 2008 [in Ukrainian].

6. Ul'berg, Z. R., Gruzina, T. G., \& Karpov ,O. V. (2008). Nanotehnologii' v medycyni: rol' koloi'dno-himichnyh procesiv [Nanotechnology in medicine: the role of colloid-chemical processes]. Visnyk NANU - Herald the National Academy of Sciences of Ukraine, 8, 28-41 [in Ukrainian].

7. Ushkalov V. O., Machus'kyj O. V., \& Kovtun V. A. et al. (2014). Vyvchennja mozhlyvostej vykorystannja nanomaterialiv $u$ biotehnologii' preparativ dlja profilaktyky sybirky tvaryn [Exploring the possibilities of using nanomaterials in biotechnology drug for the prevention of anthrax animals]. Veterynarna medycyna - Veterinary medicine, 98, 192-196 [in Ukrainian].

8. Roman'ko, M. Je. (2010). Membranotropnyj vplyv nanochastynok Aurumu ta Argentumu na intensyvnist' okysnjuval'nyh procesiv u klitynah Escherichia za umov i'h liofilizacii'/regidratacii' [Membranotropic impact of argentum and gold nanoparticles and intensity of oxidative processes in Echerichia cells under conditions of freeze]. Biologija tvaryn - Animal biology,. Vol. 12, 2, 460-473 [in Ukrainian].

9. Dybkova, S. M. (2010). Ocinka stanu mikroflory shlunkovo-kyshkovogo traktu ljudyny pry dii' nanochastynok zolota i sribla [Assessment of the microflora of the gastrointestinal tract of humans when exposed nanoparticles of gold and silver]. Visnik problem biology ta medycyny - Journal of biology and medicine issues, 3, 223-227 [in Ukrainian].

10. Arsent'eva, I. P., Glushhenko, N. N., \& Folmanis, G. Je. et al. (2007). Realizacija fiziko-himicheskih svojstv nanochastic metallov pri sozdanii biologicheski aktivnyh preparatov $v$ medicine, biologii i sel'skom 
hozjajstve [Realization of physical and chemical properties of metal nanoparticles in the creation of biologically active means in medicine, biology and agriculture]. Proceedings from The NANO 2007: II Vserossijskaja konferencija po nanomaterialam - All-Russian Conference on Nanomaterials. Novosibirsk , 323 [in Russian].

11. Rjeznichenko L. S., Gruzina T. G., Vember V. V., \& Ulberg Z. R. (2008). Vplyv metaliv-mikroelementiv na biohimichni pokaznyky bakterij-probiontiv [Effect of metals-microelements on biochemical indices of bacteriaprobiont]. Ukr. biohim. zhurn. - The Ukrainian Biochemical Journal, Vol. 80, 1, 91-101 [in Ukrainian].

12. Trachtenberg, I.M., Ulberg, Z.R., Chekman, I.S. et al. (2013). Ocinka bezpeki likarskich nanopreparativ [Safety assessment of drugs nanopreparation]. Guidelines. Kyi'v [in Ukrainian].

13. Trahtenberg I M., Dmytruha N. M., \& Apyhtina O. L. (2011). Pytannja bezpeky vyrobnyctva ta zastosuvannja nanomaterialiv [Security issues production and use of nanomaterials] Proceedings from The Ethics and nanotechnology nanosafety '11: Mizhnarodnii seminar (13 zhovtnia 2011 roku) - International seminar. (pp. 57-58). Kyi'v [in Ukrainian].

14. Dybkova, S.M., Gruzina, T.G., \& Ulberg, Z.R. et al. (2010). Ocinka bezpeki nanomaterialiv organichnoi ta neorganichnoi prirody metodom vyznachenna genotoksychnosti lujnim gel-electroforezom izoluovanich eukariotychnych clityn [Biosafety assessment of nanomaterials of organic and inorganic nature by definition of genotoxicity using alkaline gel electrophoresis of isolated eukaryotic cells]. Guidelines. Kyi'v [in Ukrainian].

15. Dybkova, S.M., Rieznichenko, L.S., \& Gruzina, T.G. et al. (2011). Ocinka mutagennosti nanomaterialiv [Assessment of nanomarerials' mutagenicity]. Guidelines. Kyi'v [in Ukrainian].

16. Imunologichni metody doslidzhen' u laboratorijah veterynarnoi' medycyny Metodychni rekomendacii' [Immunological research methods in laboratories of veterinary medicine]. (1997). Manual. Bila Cerkva [in Ukrainian].

17. Gorbatjuk O. I., Ryzhenko G. F., Zhovnir O. M., Andrijashhuk V. O., Tjutjun S. M., \& Uhovs'ka T. M. (2016). Vyvchennja mozhlyvostej zastosuvannja nanorozmirnogo sribla $v$ biotehnologii' vygotovlennja suchasnyh profilaktychnyh zasobiv [Learning opportunities for application of nanosized silver in modern biotechnology manufacturing facilities care]. Naukovo-tehnichnyj bjuleten' derzhavnogo naukovo-doslidnogo kontrol'nogo instytutu veterynarnyh preparativ ta kormovyh dobavok i instytutu biologii' tvaryn. - Scientific and technical bulletin State Research Institute for Veterinary Medicines and Feed Additives and Animal Biology Institute, Vol.17, 1, 112-117 [in Ukrainian]. 